\title{
Dobbel pylorus
}

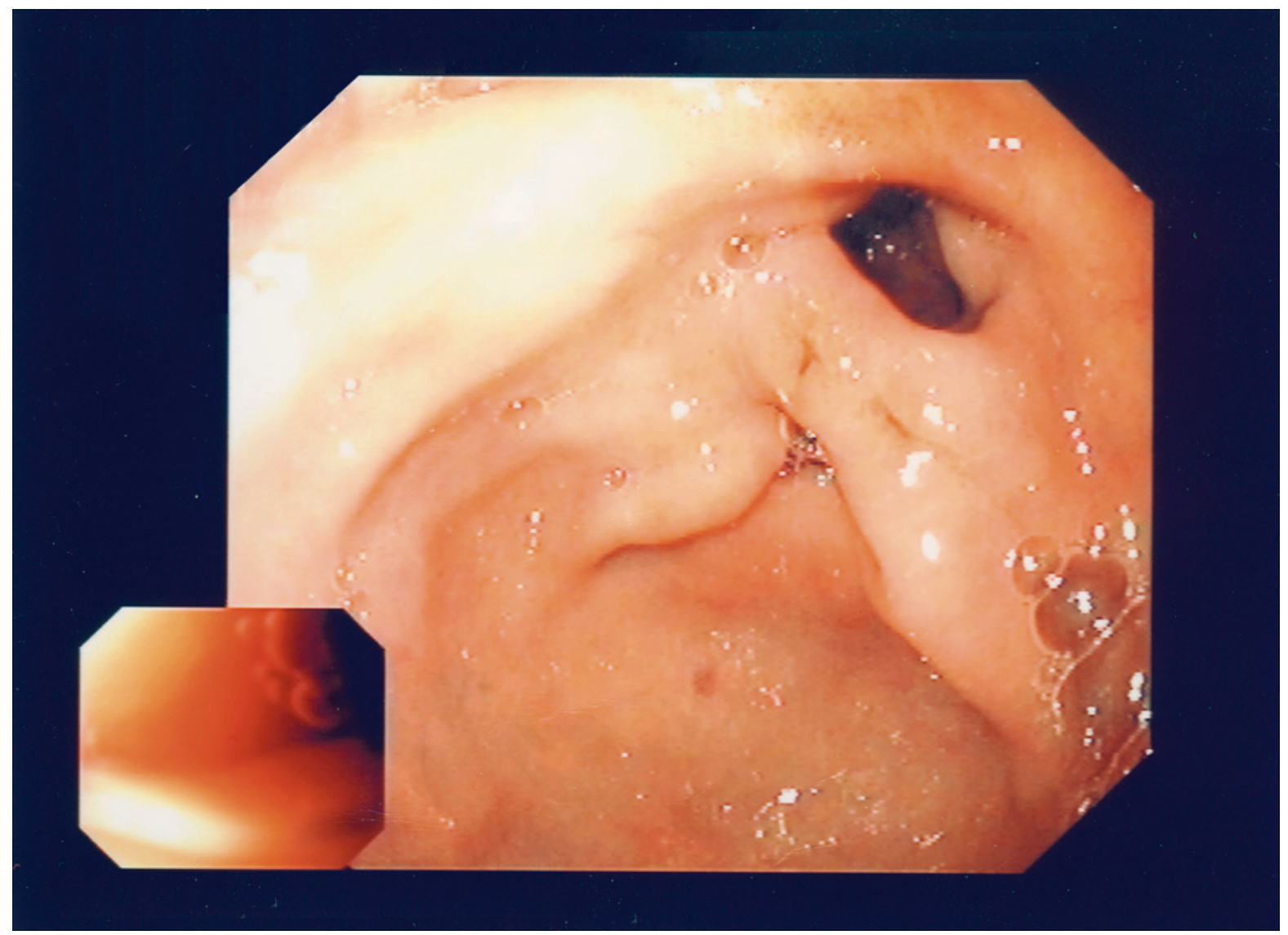

En tidligere frisk mann i 50-årene ble gastroskopert etter å ha vært plaget med epigastriesmerter ett års tid. Det ble påvist en hissig betennelse i den nederste delen av magesekken (antrum) og flere dype sår på pylorus. Helicobacterureasetest var positiv, og pasienten fikk behandling med antibiotika (klaritromycin og metronidazol) og protonpumpehemmer (pantoprazol). Magesmertene forsvant allerede etter to dagers behandling. To måneder senere kom pasienten til kontroll og var da helt symptomfri. Ved ny gastroskopi ble det imidlertid påvist to åpninger mellom ventrikkelen og duodenum (bildet). Begge åpningene ble passert med gastroskopet for å sikre at de ledet til bulbus duodeni. Sårene var ellers normalt tilhelet.

Dobbel pylorus, eller antrobulbær fistel, er en kjent, men sjelden tilstand karakterisert av to åpninger mellom antrumdelen av magesekken og bulbus duodeni. Tilstanden er beskrevet i flere publiserte kasuistikker, blant annet av Rosseland og medarbeidere tilbake i 1978 (1). Den kan være ervervet eller medfødt og gir vanligvis ingen symptomer. Det har lenge vært antatt at ervervet dobbel pylorus skyldes magesår (2), og hos vår pasient kan det se ut som en direkte utvikling fra sår til fistel. Den ekstra åpningen er, som hos vår pasient, vanligvis lokalisert på curvatura minor-siden av antrum. Dobbel pylorus er en uvanlig tilstand der vi vet lite om videre forløp. Det er antakelig helt ufarlig, men noe gastroskopører bør kunne kjenne igjen.

Pasienten har gitt samtykke til at artikkelen blir publisert.

\section{Aleksander Talgøy Holten}

aleksander.holten@gmail.com

Medisinsk avdeling

Sykehuset Innlandet, Lillehammer
Aleksander Talgøy Holten (f. 1979) er ph.d. og lege i spesialisering innen indremedisin. Forfatter har fylt ut ICMJE-skjemaet og oppgir ingen interessekonflikter.

\section{Litteratur}

1. Rosseland AR, Ruud TE, Pytte R et al. Dobbelt pylorus. To tilfelle av ulcerogen antro-bulbaer fistel. Tidsskr Nor Lægeforen 1978; 98: 1319-20.

2. Lee TH, Park SH. Double pylorus secondary to recurrent ulcer: serial endoscopy follow-up. Endoscopy 2008; 40 (suppl 2): E226.

Mottatt 8.1. 2013, første revisjon innsendt 1.2. 2013, godkjent 12.2. 2013. Medisinsk redaktør Merete Kile Holtermann. 